\title{
NASIONALISME DALAM BINGKAI KRITIK SOSIAL: KAJIAN SOSIO-PRAGMATIK TERHADAP PUISI INDONESIA MODERN
}

\author{
Novi Siti Kussuji Indrastuti \\ Fakultas Ilmu Budaya, Universitas Gadjah Mada \\ novi_indrastuti@ugm.ac.id
}

\begin{abstract}
Abstrak
Kajian ini bertujuan menemukan bentuk-bentuk kritik sosial yang mengekspresikan nasionalisme dan mengungkapkan relasi antara bentuk-bentuk kritik sosial dan nasionalisme. Puisi sebagai salah satu jenis sastra juga merefleksikan masalah sosial yang terjadi dalam masyarakat. Puisi tidak dapat dipisahkan dari realitas sosial. Respons penyair terhadap realitas sosial yang mengandung ketimpangan, ketidakadilan, dan permasalahan sosial dalam masyarakat disampaikan dalam bentuk kritik sosial yang terefleksi melalui karya-karyanya. Puisi menyatakan kritik sosial yang mengandung nasionalisme secara tidak langsung. Dengan demikian, puisi dapat dimanfaatkan sebagai media edukasi, khususnya sebagai sarana untuk menanamkan nilai-nilai nasionalisme. Metode yang dipergunakan dalam kajian ini adalah deskriptif kualitatif dengan pendekatan sosio-pragmatik. Hasil penelitian ini mengungkapkan adanya bentuk-bentuk kritik sosial yang mengekspresikan nasionalisme, antara lain nasionalisme dalam kritik terhadap masalah ekonomi, politik, pendidikan, moral, dan lingkungan. Relasi antara bentuk-bentuk kritik sosial dan nasionalisme menunjukkan bahwa kritik sosial, baik dalam bidang ekonomi, politik, pendidikan, moral, maupun lingkungan, dipergunakan sebagai media untuk menyampaikan nasionalisme.
\end{abstract}

Kata Kunci: nasionalisme; kritik sosial; sosio-pragmatik; puisi

\begin{abstract}
This study discusses finding forms of social criticism that invite nationalism and reveal the relationship between forms of social criticism and nationalism. Poetry as a genre of literature also reflects the social problems. Poetry cannot be removed from social reality. The poet's response to the social reality that contains inequality, injustice, and social conflict is conveyed in the form of social criticism reflected through poetry. Poetry about social criticism contained a sense of nationalism. It gave rise to nationalism in the quotations implicitly. Thus, poetry can be used as an educational medium, specifically as a means to instill nationalism values. The method used in this study is descriptive qualitative using sociopragmatics approach. The result of this study showed there are poetry contained a form of social criticism that reflect nationalism, including nationalism in criticizing problems of economic problems, politic, education, moral, and environmental. The relation between forms of social criticism and nationalism shows that social criticism, both in the fields of economics, politics, education, morals, and the environment, is used as a medium to convey nationalism.
\end{abstract}

Keywords: nationalism; social critics; socio-pragmatics; poetry

\section{Pendahuluan}

Realitas objektif dalam masyarakat merupakan salah satu sumber inspirasi dalam penulisan karya sastra, termasuk puisi

(Karmini, 2017:149). Puisi sebagai salah satu 
jenis karya sastra merefleksikan masalah sosial yang terjadi dalam masyarakat dengan menggunakan bahasa yang unik dan estetik. Jassin (1962:45) mengatakan bahwa ide-ide dan tanggapan-tanggapan pengarang sebagai salah satu anggota masyarakat terkandung dalam puisi yang diucapkan dengan penuh perasaan. Respons penyair terhadap realitas sosial yang mengandung ketimpangan, ketidakadilan, permasalahan sosial dalam masyarakat disampaikan dalam bentuk kritik sosial yang terefleksi melalui karya-karyanya.

Puisi selalu mengalami perubahan dari masa ke masa disebabkan adanya dinamika perubahan evolusi selera, konsep estetik, dan realitas sosial yang menjadi objek di dalamnya. Akan tetapi, ada satu hal yang tidak berubah dalam puisi, yakni puisi itu mengekspresikan sesuatu secara tidak langsung (Riffaterre, 1978:2). Ucapan tidak langsung itu ialah menyatakan suatu hal dengan arti yang lain (Pradopo, 2017:332). Dalam hal ini, puisi yang menyatakan kritik sosial di dalamnya terkandung rasa nasionalisme. Dengan kata lain, nasionalisme diungkapkan dalam bentuk kritik sosial. Hal tersebut disebabkan nasionalisme dalam puisi dikemukakan secara tidak langsung. Karya sastra yang berupa puisi dapat dimanfaatkan sebagai media edukasi, khususnya sebagai sarana untuk menanamkan nilai-nilai nasionalisme. Dengan demikian, puisi sebagai salah satu jenis karya sastra memiliki kontribusi yang cukup signifikan dalam pembangunan karakter bangsa.
Smith (1979:1) memaknai nasionalisme sebagai gerakan ideologis untuk meraih dan memelihara otonomi, kohesi dan individualitas bagi satu kelompok sosial tertentu yang diakui oleh beberapa anggotanya untuk membentuk atau menentukan satu bangsa yang sesungguhnya atau yang berupa potensi saja. Snyder (1964:23) memaknai nasionalisme sebagai suatu bentuk emosi yang kuat yang mendominasi pikiran dan tindakan politik kebanyakan anggota masyarakat. Nasionalisme merupakan salah satu sarana untuk menciptakan persatuan. Dengan kata lain, nasionalisme dapat menjadi alat pemersatu bangsa. Dengan demikian, nasionalisme merupakan hal penting untuk ditumbuhkan dan dipelihara.

Salah satu wujud nasionalisme adalah bersikap kritis terhadap kehidupan berbangsa dan bernegara. Nasionalisme adalah roh penggerak segenap elemen dalam kehidupan berbangsa dan bernegara. Nasionalisme terbentuk dari interaksi antarelemen dalam suatu bangsa dan tanggapan bangsa itu terhadap lingkungan, sejarah, dan cita-citanya (Efendi, 2008). Pengungkapan kritik, aspirasi, dan solusi terhadap permasalahan bangsa dan negara merupakan penanda kecintaan terhadap tanah air. Dalam hal ini, puisi dapat dimanfaatkan sebagai media penyampai kritik sosial. Dengan demikian, puisi merupakan wujud rasa nasionalisme yang dikemas dalam bentuk kritik sosial. Oleh karena itu, nasionalisme dalam bingkai kritik sosial yang terkandung dalam puisi penting untuk dikaji lebih lanjut. Berdasarkan latar belakang tersebut di atas, rumu- 
san masalah dalam penelitian ini adalah (a) bentuk-bentuk kritik sosial yang mengekspresikan nasionalisme, (b) relasi antara bentuk-bentuk kritik sosial dengan nasionalime. Sesuai dengan rumusan masalah tersebut, tujuan dari penelitian ini adalah menemukan bentuk-bentuk kritik sosial yang mengekspresikan nasionalisme, dan mengungkapkan relasi antara bentuk-bentuk kritik sosial dan nasionalisme

Ada beberapa penelitian yang berkaitan dengan penelitian ini, antara lain penelitian Ni'mah (2017) yang berjudul "Pandangan Nasionalisme dalam Puisi Maḥmūd Darwisy dan Rendra dalam Analisis Sastra Banding". Penelitian ini membahas pandangan nasionalisme dalam puisi Arab dan Indonesia. Hal yang dibandingkan dari dua puisi tersebut adalah pandangan tentang negara dan perjuangan melawan penjajah. Penelitian ini menghasilkan adanya perbedaan dan persamaan antara dua karya sastra berbentuk puisi dari dua negara, yaitu Arab dan Indonesia. Puisi Arab "Bitāqah Hāwiyyah" karya Darwisy merepresentasikan bahwa negara adalah rumah bagi rakyat Palestina. Adapun puisi "Gugur" karya Rendra menggambarkan bahwa negara itu adalah jiwa bagi para penduduk Indonesia. Kedua puisi tersebut memiliki perspektif yang berbeda dalam memandang suatu negara. Akan tetapi, kedua puisi tersebut memiliki wujud rasa nasionalisme yang sama, yakni perjuangan melawan penjajahan.

Wildan (2009) dalam disertasinya yang berjudul "Nasionalisme: Kajian Novel A. Hasjmy" mengungkapkan nasionalisme yang digambarkan dalam tujuh novel yang ditulis oleh A. Hasjmy, seorang penulis Aceh. Novel tersebut adalah Melalui Jalan Raya Dunia (1938), Bermandi Cahaya Bulan (1939), Suara Azan dan Lonceng Gereja (1940), Nona Pressroom (1951), Elly Gadis Nica (1951), Meurah Djohan: Sultan Aceh Pertama (1976), and Tanah Merah: Digul Bumi Pahlawan Kemerdekaan Indonesia (1976). Tujuan penelitian ini untuk menganalisis nasionalisme dan kecocokannya dalam konteks politik Indonesia. Penelitian ini mengkaji unsur-unsur nasionalisme, seperti doktrin dan teknik penulisan yang digunakan oleh penulis.

Nasionalisme dalam karya sastra juga dibahas dalam penelitian Sari (2017) yang berjudul “Gagasan Nasionalisme Pramoedya Ananta Toer dalam Karya Tetralogi Buru". Penelitian tersebut membahas nasionalisme dalam Tetralogi Buru yang terdiri atas Bumi Manusia, Anak Semua Bangsa, Jejak Langkah, dan Rumah Kaca.. Dari hasil penelitian ini diperoleh gambaran tentang perjuangan kaum pribumi melawan ketidakadilan yang dilakukan kolonialisme terhadap bangsa Indonesia.

Purnawati (2017) dalam penelitiannya yang berjudul "Kritik Sosial dan Nasionalisme dalam Novel Gading-Gading Ganesha (3G) Karya Dermawan Wibisono" mendeskripsikan kritik sosial dan nasionalisme yang terdapat dalam novel Gading-Gading Ganesha (3G) karya Dermawan Wibisono. Objek penelitian ini adalah bentuk-bentuk kritik sosial dan nasiona- 
lisme. Hasil penelitian ini menunjukkan bahwa bentuk-bentuk kritik sosial yang terdapat dalam novel Gading-Gading Ganesha (3G) dibagi menjadi beberapa bagian sebagai berikut: (a) Kritik sosial masalah moral (b) kritik sosial masalah politik, (c) kritik sosial masalah keluarga. Bentuk-bentuk nasionalisme yang terdapat dalam novel Gading-Gading Ganesha (3G) adalah (a) nasionalisme kenegaraan yang terdiri atas kepedulian terhadap tanah air, (b) nasionalisme budaya.

Wiyatmi (2013) membahas nasionalisme dalam artikelnya yang berjudul "Konstruksi Nasionalisme dalam Novel-Novel Indonesia Prakemerdekaan (Student Hijo dan Salah Asuhan)". Dalam penelitian tersebut diungkapkan konstruksi nasionalisme yang terdapat dalam novel-novel Indonesia prakemerdekaan, khususnya Studet Hijo dan Salah Asuhan dengan menggunakan perspektif teori hegemoni Gramsci. Hasil analisis menunjukkan bahwa kedua novel tersebut mengkonstruksi ideologi nasionalisme melawan kolonialisme pada era penjajahan Belanda. Kedua novel tersebut juga menunjukkan tugasnya sebagai medan pertarungan ideologi nasionalisme melawan kolonialisme.

Efendi (2008) dalam artikelnya yang berjudul "Gagasan Nasionalisme dan Wawasan Kebangsaan dalam Novel Indonesia Modern" menggali gagasan nasionalisme dan wawasan kebangsaan yang dapat dilakukan dengan cara memahami gagasan, konsep, dan pandangan yang disampaikan oleh para pemikir pada masa lalu. Di samping melalui dokumen kesejarahan, gagasan, konsep, dan pandangan tersebut juga dapat ditelusuri melalui karya-karya budaya. Salah satu wujud hasil kebudayaan tersebut adalah karya sastra. Karya sastra dapat menjadi sarana bagi pengarang untuk menyampaikan pikiran, perasaan, dan tanggapan mengenai suatu peristiwa sejarah. Pikiran, gagasan, dan pandangan pengarang tersebut dapat berkaitan dengan rasa nasionalisme dan wawasan kebangsaan yang dituangkan dalam karya sastra. Gagasan nasionalisme dan wawasan kebangsaan diekspresikan oleh pengarang melalui struktur naratif, seperti pada (a) cerita yang bertokoh dan berlatar masa revolusi Indonesia, (b) sikap, perilaku, dan gagasan tokoh, dan (c) deskripsi narator.

Berdasarkan beberapa penelitian yang dipaparkan di atas, penelitian mengenai nasionalisme dalam karya sastra yang berjenis puisi belum banyak dilakukan. Di samping itu, karena puisi merupakan karya unik yang mengemukakan sesuatu secara tidak langsung, nasionalisme yang terkandung di dalamnya juga tidak dikemukakan secara eksplisit, tetapi dikemas dalam bentuk kritik sosial. Dengan demikian, dalam kajian ini diungkapkan nasionalisme yang ada di balik kritik sosial dalam teks puisi. Tentu saja, hal tersebut merupakan hal yang menarik dan inovatif.

Karya sastra selalu terlibat dalam kehidupan konkret manusia, bukan sekadar gambaran abstrak sebuah dunia alternatif dan imajinatif. Stephen Greenblatt-pelopor kritik 
New Historicism-menolak pandangan bahwa sastra hanyalah merupakan dunia alternatif (Taum, 2015:ix). Karya sastra tidak ada yang terlahir dari situasi tabularasa, semua sastra apa pun alirannya dan bagaimanapun dihadirkannya selalu berpijak pada masyarakat sebagai hasil interaksi pengarang dengan lingkungan sosialnya (Manuaba: 2014:10). Dengan kata lain, tidak ada karya sastra yang jatuh dari langit (Toda, 1980; Rendra, 1984). Menurut Damono (1984:1), sastra melukiskan kehidupan dan kehidupan itu adalah realitas sosial. Yang dimaksud dengan kehidupan mencakup hubungan antar masyarakat, antarmasyarakat dengan orang-seorang, antar manusia, dan antar peristiwa yang terjadi dalam batin seseorang. Luxemburg (1984:23-24) berpendapat bahwa karya sastra merupakan gejala sosial yang ditulis pada suatu periode waktu tertentu dan berhubungan langsung dengan norma-norma dan adat-istiadat suatu zaman. Sastra merekam seluruh kejadian sejarah, peristiwa sosial, dan ketimpangan sosial yang ada, yang tidak terucapkan dalam "narasi besar" (grand narrative) (Putra, 6455: ${ }^{0}$ 8). Dalam karya sastra terekam persoalan sosial, ekonomi, politik, sejarah, filsafat, etika, moral, psikologi, lingkungan, religi, dan hal lain yang ada dalam masyarakat (Manuaba, 2014:6).

Jdanov dalam Escarpit (2005:8) mengatakan bahwa sastra harus dipandang dalam hubungan yang tak terpisahkan dengan kehidupan masyarakat, latar belakang unsur sejarah, serta unsur sosial yang me- mengaruhi pengarang. Sosiologi sastra adalah pemahaman terhadap karya sastra dengan mempertimbangkan aspek-aspek kemasyarakatannya (Ratna, 2008:3). Penelitian-penelitian sosiologi sastra menghasilkan pandangan bahwa karya sastra adalah ekspresi dan bagian dari masyarakat dan dengan demikian, memiliki keterkaitan resiprokal dengan jaringanjaringan sistem dan nilai dalam masyarakat tersebut (Soemanto, 1993). Sastra menggambarkan penderitaan-penderitaan hidup manusia, pikiran-pikiran serta gagasan-gagasannya, perjuangannya, kasih sayangnya, dan segala sesuatu yang dialaminya (Karmini, 2017:150). Sastra juga melukiskan jiwa zaman (zeitgeist) suatu bangsa, sejarah pemikiran manusia, semangat nasionalisme dan patriotisme, ideologi dan idealisme, serta gagasan-gagasan baru (Manuaba, 2014:8).

Dalam kajian ini juga digunakan pendekatan pragmatik sastra. Istilah pragmatik menunjuk pada efek komunikasi yang dirumuskan dalam istilah Horatius, yaitu bahwa seorang seniman bertugas untuk docere 'memberi ajaran' dan delectare 'memberi kenikmatan', bahkan sering ditambah dengan movere 'menggerakkan pembaca ke kegiatan yang bertanggung jawab; seni menggabungkan sifat utile 'bermanfaat' dan dulce "manis", "enak", dan menyenangkan (Teeuw, 1984:51). Konsep pragmatik sastra yang dikemukakan oleh Sidney sejalan dengan pendapat Horatius, yakni sastra hendaknya mempunyai fungsi to teach (memberi ajaran) dan delight (memberikan kenikmatan) (Abrams, 1981). Melalui karya sastra, 
masyarakat pembaca dapat mengalami proses penyadaran inklusif yang tanpa didoktrin dan didikte (Manuaba, 2014:3). Selanjutnya, dikatakan bahwa dalam menghayati sastra, masyarakat pembaca dengan nyaman mengalami berbagai pencerahan karena dalam sastra terlukis berbagai problematika dan alternatif kehidupan yang bermanfaat untuk menyikap kehidupan yang baik dan bijak (Manuaba, 2014:3). Dengan demikian, karya sastra yang baik diharapkan dapat memengaruhi pembacanya ke arah yang lebih positif.

Pradopo (1997:34) mengemukakan bahwa kritik pragmatik memandang karya sastra sebagai sesuatu yang dibangun untuk mencapai efek-efek tertentu pada diri pembaca atau pendengarnya, seperti efek-efek kesenangan, estetik, dan edukasi. Kritik pragmatik menilai karya sastra berdasarkan keberhasilannya mencapai tujuan. Sehubungan dengan hal tersebut, jika sebuah karya sastra dapat memuaskan dan menyenangkan pembacanya, karya tersebut dapat dianggap sebagai karya yang baik. Di samping itu, penelitian pragmatik mengandalkan aspek guna dan nilai karya bagi pembacanya. Dengan demikian, pendekatan pragmatik bertujuan untuk mengetahui bahwa sebuah karya sastra mampu memberikan ajaran, memberikan kenikmatan, dan menggerakkan pembaca ke arah kegiatan yang bertanggung jawab. Pendekatan pragmatik memandang karya sastra sebagai sarana untuk menyampaikan tujuan tertentu kepada pembacanya. Tujuan tersebut dapat berupa tujuan pendidikan, moral, politik, agama, maupun tujuan lainnya (Pradopo, 1997:34). Pada dasarnya karya sastra berfungsi untuk mengarahkan manusia ke arah yang lebih baik atau positif. Teeuw (2003:21) menyatakan bahwa karya sastra adalah alat untuk mengajar, buku petunjuk, dan buku instruksi atau pengajaran.

Kritik adalah masalah analisis dan evaluasi terhadap sesuatu dengan tujuan meningkatkan pemahaman, memperluas apresiasi, atau membantu memperbaiki suatu pekerjaan atau aktivitas (Curtis dkk., 1996:284). Kritik sosial dapat diartikan sebagai ironi atau sindiran terhadap suatu hal atau peristiwa dalam masyarakat ketika terjadi suatu konfrontasi dengan realitas berupa ketidakadilan. Kritik sosial biasanya mengemuka saat kehidupan dipandang tidak harmonis dan saat masalah-masalah sosial mengakibatkan dampak-dampak negatif dalam masyarakat. Susanto (1982) menyatakan bahwa kritik sosial adalah aktivitas yang berhubungan dengan penilaian (judging), perbandingan (comparing), dan pengungkapan (revealing) mengenai kondisi sosial yang terkait dengan nilai-nilai yang dianut atau dijadikan pedoman. Kritik sosial merupakan aktivitas umum yang dalam melakukannya tidak perlu menunggu adanya penemuan filosofis atau invensi tertentu (Walzer, 1985:30).

Parera (2006:142) mengatakan bahwa pada era kini kritik sosial dapat dikemukakan melalui berbagai saluran yang paling berpengaruh, baik karena keluasan jangkauan maupun ke- 
cepatan dan frekuensinya, seperti surat kabar, radio, televisi, maupun jenis media cetak lain. Kritik sosial juga dapat dikemukakan melalui karya sastra, termasuk puisi.

Metode merupakan cara kerja agar dapat memahami objek yang menjadi sasaran penelitian. Metode yang digunakan dalam penelitian ini adalah metode kualitatif. Metode kualitatif bersifat deskriptif dan cenderung menggunakan analisis. Dalam penelitian kualitatif, peneliti bertolak dari data, memanfaatkan teori yang ada sebagai bahan penjelas, dan bisa berakhir dengan suatu "teori" baru. Kriyantono (2006) mengatakan bahwa riset kualitatif betujuan untuk menjelaskan fenomena dengan sedalamdalamnya melalui pengumpulan data sedalam-dalamnya.

Metode pengumpulan data dilakukan dengan studi kepustakaan. Sajak-sajak dikumpulkan dari beberapa sumber. Studi pustaka juga dilakukan untuk memperoleh referensi dan data lain yang mendukung analisis dalam kajian ini.

Dalam kajian ini yang dianalisis adalah gambaran masalah korupsi dan dampaknya dalam puisi Indonesia modern serta wacana antikorupsi bagi pembacanya.

Analisis tersebut dilakukan berdasarkan langkah-langkah berikut: (a) membaca teksteks puisi karya penyair Indonesia, (b) mengkategorisasikan teks-teks puisi yang mengandung kritik sosial, (c) menganalisis bentuk-bentuk kritik sosial yang mengekspresikan nasionalisme, (d) menganalisis relasi antara bentuk-bentuk kritik sosial dengan nasionalisme, dan (e) menarik kesimpulan.

\section{Nasionalisme dalam Kritik terhadap Masa- lah Ekonomi}

Kritik terhadap perekonomian Indonesia sering dijumpai dalam puisi Indonesia modern. Misalnya, dalam sajak karya Taufik Ismail berjudul "Seratus Juta" yang membahas tentang kemiskinan di Indonesia. Puisi ini mengungkapkan kemiskinan karena banyaknya pengangguran. Berikut penggalan puisi "Seratus Juta" karya Taufik Ismail.
Umat miskin dan penganggur berdiri hari ini Seratus juta banyaknya
Di tengah mereka tak tahu akan berbuat apa
("Seratus Juta", Ismail, 2000)

Baris pertama dalam penggalan tersebut 'umat miskin dan pengganggur berdiri hari ini' menggambarkan kondisi kemiskinan yang disebabkan tingginya angka pengangguran di Indonesia saat ini. Kritik terkait keadaan ekonomi menunjukkan adanya keprihatinan terhadap pengangguran yang terjadi dalam masyarakat Indonesia. Perhatian terhadap pengangguran di Indonesia, ditunjukkan dalam baris-baris berikutnya dalam puisi ini.

Saudaraku yang sirna nafkah, tanpa kerja
berdiri hari ini
Seratus juta banyaknya
Kita mesti berbuat sesuatu, betapun sukarnya.

("Seratus Juta", Ismail, 2000)

Kutipan tersebut di atas menunjukkan adanya kepedulian dan keprihatinan terhadap 
kondisi perekonomian Indonesia yang buruk. Hal tersebut diungkapkan dalam baris 'Kita mesti berbuat sesuatu, betapun sukarnya'. Karya ini dimaksudkan untuk membangkitkan semangat nasionalisme dalam mengentaskan kemiskinan di Indonesia.

Dalam sajak lain juga terdapat kritik terhadap aspek ekonomi di Indonesia, yakni dalam sajak "Gumam Sehari" karya Wiji Thukul. Dalam sajak ini dikemukakan kritik terhadap perekonomian di Indonesia, khususnya yang terkait dengan masalah kemiskinan. Rakyat miskin digambarkan hanya bisa makan seadanya. Penggambaran tersebut terdapat dalam kutipan berikut ini.

di ujung sana ada tempat penyembelihan sapi dan kami kebagian bau kotoran air selokan dan tai di ujung sana ada perusahaan daging abon setiap pagi kami beli kuahnya dimasak campur sayur

(“Gumam Sehari-hari”, Thukul, 1989)

Dalam penggalan di atas, tampak adanya keprihatinan terhadap kehidupan rakyat miskin, misalnya dalam baris pertama dan kedua 'di ujung sana ada tempat penyembelihan sapi','dan kami kebagian bau' yang berarti bahwa rakyat miskin tak mampu membeli daging.

Selanjutnya, pada baris 'di ujung sana ada perusahaan daging abon', 'setiap pagi kami beli kuahnya' juga menggambarkan ketidakmampuan rakyat miskin untuk mencukupi kebutuhan hidupnya. Di samping itu, tampak adanya jurang pemisah yang lebar antara si kaya dan si miskin. Dengan demikian, dalam puisi tersebut tampak adanya perhatiankhusua terhadap rakyat miskin. Kemiskinan merupakan masalah besar bagi suatu negara. Kritik sosial semacam ini lahir karena adanya dorongan nasionalisme.

\section{Nasionalisme dalam Kritik terhadap Masa- lah Politik}

Dalam puisi Indonesia modern banyak ditemukan kritik terhadap situasi politik di Indonesia, antara lain dalam sajak "Malu (Aku) Jadi Orang Indonesia" karya Taufik Ismail. Puisi tersebut menyinggung dunia politik Indonesia saat ini yang sedang dalam kondisi kurang baik. Puisi ini mengritik kondisi politik pada masa sekarang dibandingkan dengan kondisi politik masa lalu. Hal ini dijelaskan dalam kutipan sajak berikut ini.

\footnotetext{
Di negeriku yang didirikan pejuang religius Kini dikuasai pejabat rakus

Kejahatan bukan kelas maling sawit melainkan permainan lahan duit

Di negeriku yang dulu agamis

Sekarang bercampur liberalis sedikit komunis ...

("Malu (Aku) Jadi Orang Indonesia", Ismail, 2000)
}

Baris-baris sajak tersebut di atas menggambarkan keadaan politik saat ini yang pelakunya didominasi oleh para "pejabat rakus" dengan "permainan uang" kelas kakap. Kondisi seperti ini berbeda jauh dengan kondisi masa lalu yang lebih agamis. Kritik terhadap kondisi politik di negeri ini dilanjutkan pada baris berikutnya.

Telah habis sabarku

Telah habis sabar kami

Pada presiden yang tak solutif 
Pada dewan dan majelis yang tak bermufakat Pada semua bullshit yang menggema saat pemilu

("Malu (Aku) Jadi Orang Indonesia", Ismail, 2000)

Baris-baris sajak di atas menunjukkan bahwa lembaga eksekutif dan legislatif tidak melaksanakan tugas sebagaimana mestinya. Dengan kata lain, baris-baris sajak tersebut mengkritisi kinerja presiden, dewan, maupun majelis. Program-program yang disertai dengan janji-janji dan harapan-harapan yang disampaikan saat kampanye Pemilu ternyata hanya menggema menjadi kebohongan dan kepalsuan belaka. Baris-baris selanjutnya dalam puisi ini menunjukkan kritik terhadap politik, yaitu pada baris 'hokum-hukum keadilan tergadai kepentingan politis' yang mengkritik ranah hukum yang "ditunggangi" kepentingan politik.

Nasionalisme di sini tampak dalam diri si aku yang menyatakan keprihatinan dengan cara menggambarkan situasi politik yang "kotor" di negeri ini. Dengan mengemukakan kritik terhadap situasi politik tersebut,si aku secara tidak langsung menyerukan perlunya terjadi perubahan sehingga sistem pemerintahan dapat berjalan dengan baik dan situasi politik menjadi kondusif.

Kritik terhadap masalah politik juga ditemukan dalam sajak "Peringatan" karya Wiji Thukul. Kritik tersebut tecermin dalam baris-baris berikut ini.

jika rakyat pergiketika penguasa pidato kita harus hati-hati barangkali mereka putus asa
("Peringatan", Thukul, 1986)

Dalam penggalan sajak tersebut, baris satu dan dua menceritakan kondisi negara demokrasi yang tidak berjalan sebagaimana mestinya. Komunikasi antara pemerintah dan rakyatnya tidak berlangsung dua arah. Baris 'jika rakyat pergi' dan 'ketika penguasa pidato' menggambarkan ketidaksetujuan rakyat akan sesuatu, tetapi mereka tidak diberi kesempatan untuk menyampaikan ketidak setujuan itu. Oleh karena itu, rakyat pun menjadi tidak peduli lagi terhadap pemerintah.

Dalam sajak "Peringatan" karya Wiji Thukul ini juga dilukiskan adanya ketidakadilan yang menimpa rakyat jelata. Hal tersebut tampak dalam baris-baris sajak di bawah ini.

apabila usul ditolak tanpa ditimbang suara dibungkam kritik dilarang tanpa alasan dituduh subversif dan mengganggu keamanan maka hanya ada satu kata: lawan!

(“Peringatan", Thukul, 1986)

Kutipan baris-baris sajak di atas menunjukkan tidak adanya hak kebebasan berpendapat dan berbicara bagi rakyat. Apabila rakyat berani berpendapat, dituduh subversif dan mengganggu keamanan.

Semangat nasionalisme dalam sajak "Peringatan" karya Thukul tersebut tampak pada baris terakhir, yakni 'maka hanya ada satu kata: lawan!'. Dalam baris sajak tersebut tampak adanya persuasi supaya jangan hanya diam saja menyikapi situasi yang seperti itu. Tidak adanya kebebasan berbicara dan berpendapat harus dilawan sehingga kehidupan yang demokratis di Indonesia dapat berlangsung dengan 
baik dan rakyat jelata dapat memperoleh hak untuk berbicara dan berpendapat sehingga keadilan dapat tercipta.

\section{Nasionalisme dalam Kritik terhadap Ma- salah Pendidikan}

Sistem pendidikan di Indonesia seringdibahas dalam puisi. Puisi yang berisi kritik terhadap pendidikan di Indonesia terdapat dalam sajak karya W.S. Rendra yang berjudul "Sajak Anak Muda” dan "Sajak Sebatang Lisong". Dalam sajak "Sajak Anak Muda" diungkapkan kritik mengenai sistem pendidikan Indonesia yang kurang kontekstual dan humanis. Hal tersebut tampak dalam penggalan "Sajak Anak Muda” karya W.S. Rendra berikut ini.

Kita adalah angkatan gagap yang diperanakkan oleh angkatan takabur. Kita kurang pendidikan resmi di dalam hal keadilan,

karena tidak diajarkan berpolitik, ...

\section{(“Sajak Anak Muda”, Rendra, 1996)}

Dalam kutipan tersebut terdapat kritik mengenai konten pendidikan yang ada di Indonesia. Dalam sajak tersebut di atas dikemukakan bahwa pendidikan di Indonesia belum tepat sasaran karena dalam pendidikan resmi tidak diajarkan tentang cara berpolitik.

Dalam "Sajak Anak Muda" ini juga terkandung kritik terhadap sistem pendidikan yang tidak membumi dan tidak kontekstual karena justru arah pendidikan cenderung berkiblat ke Barat, seperti tampak dalam kutipan sajak di bawah ini.

Pendidikan negeri ini berkiblat ke Barat. Di sana anak-anak memang disiapkan untuk menjadi alat dari industri. Dan industri mereka berjalan tanpa henti. Tetapi kita dipersiapkan menjadi alat apa? Kita hanya menjadi alat birokrasi! Dan birokrasi menjadi berlebihan tanpa kegunaan menjadi benalu di dahan. Gelap. Pandanganku gelap.

Pendidikan tidak memberikan pencerahan. Latihan-latihan tidak memberi pekerjaan. Gelap. Keluh kesahku gelap.

Orang yang hidup di dalam pengagguran.

(“Sajak Anak Muda”, Rendra, 1977)

Kutipan tersebut mempertegas bahwa pendidikan di Indonesia akan sia-sia apabila sistem pendidikannya tidak disesuaikan dengan kondisi sosial-budaya di Indonesia. 'Pendidikan tidak memberikan pencerahan' sehingga pengangguran justru merajalela. Kritik terhadap sistem pendidikan yang tidak kontekstual ini mencerminkan rasa nasionalisme karena mengandung kepedulian yang besar terhadap pendidikan generasi muda Indonesia dan masa depan bangsa.

Kritik terhadap pendidikan juga dikemukakan Rendra dalam karyanya yang berjudul "Sajak Sebatang Lisong". Hal tersebut dapat dilihat dalam potongan sajak berikut ini.

Matahari terbit.

Fajar tiba.

Dan aku melihat delapan juta kanak-kanak tanpa pendidikan.

("Sajak Sebatang Lisong", Rendra, 1996)

Dalam kutipan sajak tersebut di atas tampak adanya kritik terhadap dunia pendidikan, 
yakni tentang anak-anak yang belum seluruhnya mendapat hak memperoleh pendidikan yang layak. Kritik tersebut diungkapkan secara eksplisit pada baris ketiga dan keempat, yakni 'Dan aku melihat delapan juta kanak-kanak, tanpa pendidikan'. Dalam baris tersebut terkandung kritik tentang kinerja pemerintah yang masih mengesampingkan sektor pendidikan. Kritik semacam ini menunjukkan adanya semangat nasionalisme karena secara tidak langsung menunjukkan kepedulian terhadap pendidikan generasi muda harapan bangsa. Sektor pendidikan ini sangat penting karena generasi muda inilah yang akan menentukan masa depan bangsa.Pendidikan merupakan salah satu aspek penting untuk menunjang masa depan bangsa.

\section{Nasionalisme dalam Kritik terhadap Masalah Moral}

Dalam puisi Indonesia modern terdapat pula kritik terhadap moral. Moral berkaitan dengan kondisi mental seseorang dalam melakukan sesuatu. Dalam puisi Indonesia modern tampak adanya kecenderungan kritik moral yang tertuju pada pihak pemerintah. Hal tersebut tampak dalam sajak “Tangisku Pertiwi" dalam buku Kalimantan dalam Puisi Indonesia.

Engkau Gayuskan Indonesia, Dari hilangnya kejujuran. Engkau Gayuskan Indonesia, Dari jerit tangis rakyat jelata. Engkau rayakan Gayus, Untuk Indonesia menyanyi.
(Kumpulan Puisi Kalimantan dalam Puisi Indonesia, 2011)

Sajak tersebut di atas mengangkat figur koruptor yang pernah sangat populer pada masanya, yakni Gayus. Dalam kutipan tersebut nama 'Gayus' disebut berulang-ulang dan diasosiasikan dengan hal yang buruk. Misalnya, pada baris 'Engkau Gayuskan Indonesia', 'Dari hilangnya kejujuran' yang bermakna bahwa 'Gayus' merupakan simbol ketidakjujuran. Dalam baris berikutnya, yakni 'Engkau Gayuskan Indonesia', 'Dari jerit tangis rakyat jelata' menggambarkan bahwa Gayus mengundang tangis bagi rakyat jelata karena ulahnya yang tidak bermoral, yakni melakukan tindak korupsi.

Kritik moral juga terdapat dalam sajak “Tentang Hukum" dalam Pro Justisia. Sajak ini mengungkapkan kritik terhadap jalannya hukum di Indonesia. Seharusnya, aparat hukum bekerja secara adil dan penuh integritas dalam menyelesaikan segala permasalahan yang ada di Indonesia. Akan tetapi, hukum di Indonesia berjalan sebaliknya. Hal ini diungkapkan dalam penggalan berikut ini.

\footnotetext{
Nyatanya hukum pada hari ini

Adalah orang-orang yang pandai berdagang Orang-orang yang tertimbun pada gusuran Pohon-pohon rimbun kering kerontang Pejabat-pejabat yang sering menuding Dan menadahkan tangan

Dan hakim-hakim yang bermata telanjang
}

(Pro justisia, 1997)

Kutipan tersebut menunjukkan praktik hukum yang sebenarnya terjadi di negara ini. Hukum bisa diperjualbelikan seperti yang 
diungkapkan dalam baris 'Nyatanya hukum pada hari ini adalah orang-orang yang pandai berdagang'. Selanjutnya, ditegaskan lagi dengan baris kelima sampai ketujuh yang mengungkapkan bahwa pejabat dan hakim sudah tidak lagi bermoral, yakni diibaratkan dengan 'hakim-hakim yang bermata telanjang' bermakna bahwa hakim tidak punya rasa malu dalam memutuskan suatu kasus hukum berdasarkan kepentingan tertentu.

Kedua puisi yang berisi kritik moral ini menunjukkan keresahan terhadap kondisi Indonesia yang manusianya semakin tidak bermoral. Dalam kritik terhadap moral tersebut sebenarnya terkandung upaya penyadaran sekaligus harapan untuk menjadi lebih baik sehingga hal tersebut secara tidak langsung merupakan wujud nasionalisme.

\section{Nasionalisme dalam Kritik terhadap Ma- salah Lingkungan}

Permasalahan-permasalahan mengenai lingkungan di Indonesia juga cukup banyak dikemukakan dalam puisi Indonesia modern. Banyak puisi yang menyinggung kondisi lingkungan yang telah rusak atau tercermar. Hal tersebut dapat dilihat dalam sajak "Sungaiku Sayang Sungaiku Malang" karya Birhasan Ismail yang mengungkapkan keadaan sungai yang tercemar karena ulah manusia.

\footnotetext{
Sementara

Mentari membujukmu tersenyum

Wajahmu cemberut

Kau sisihkan pemberiannya itu, karena

Kekeruhan bagaikan adukan lumpur

Kuning
}

\author{
Pekat \\ Pentulan sang surya tumpul \\ Di permukaan \\ ...
}

("Sungaiku Sayang Sungaiku Malang", Ismail, 2000)

Kutipan tersebut menceritakan keadaan sungai yang sangat kotor dan pekat akibat pencemaran lingkungan. Kata 'kau' dalam sajak tersebut merujuk pada sungai. Kutipan tersebut secara umum menggambarkan warna kuning dan keruh dari sebuah sungai. Hal ini terjadi karena ulah manusia yang tidak menjaga lingkungannya. Kritik terhadap lingkungan ini terdapat dalam kutipan berikut.

\author{
Mereka berceloteh menggerutu \\ Saat kekeruhan itu membuat diri \\ Pada ember-ember mereka \\ Huh keruh \\ Hih kuning \\ Cah bagaikan tanah \\ Yakh... jijik \\ Kenapa? \\ Mengapa keruh \\ Siapa yang harus disalahkan?
}

("Sungaiku Sayang Sungaiku Malang”, Ismail, 2000)

Sungai yang tercemar meresahkan masyarakat. Akan tetapi, pencemaran tersebut ternyata disebabkan masyarakat sekitar yang tidak mau menjaga dan melestarikan lingkungannya. Baris 'siapa yang harus disa-lahkan' merupakan kalimat tanya retoris yang jawabannya dikembalikan kepada pembacanya sebagai hal yang penting untuk direnungkan. Kritik terhadap lingkungan dalam puisi tersebut mencerminkan kepedulian terhadap kondisi lingkungan di tanah air. Hal tersebut merupa- 
kan wujud nasionalisme yang dituangkan dalam puisi.

Dalam puisi lain, kritik terhadap lingkungan juga diungkapkan dalam sajak Chairil Anwar yang berjudul "Suara Malam". Hal tersebut tampak dalam baris-baris sajak berikut ini.

Dunia badai dan topan

Manusia mengingatkan "Kebakaran di Hutan" Jadi kemana

Untuk damai dan reda?

Mati.

Barang kali ini diam aku saja

Dengan ketenangan selama bersatu

Mengatasi suka dan duka.

Kekebalan terhadap debu dan nafsu.

Berbaring tak sedar

Seperti kapal pecah di dasar lautan

Jemu dipukul ombak besar

Atau ini.

Peleburan dalam Tiada

Dan sekali akan menghadap cahaya.

Ya Allah! Badanku terbakar-sela samar

Aku sudah melewati batas.

Kembali? Pintu tertutup dengan keras.

(“Suara Malam”, Anwar, 2016)

Dalam potongan sajak tersebut di atas dikemukakan tentang peristiwa kebakaran hutan. Kebakaran hutan terkadang disebabkan oleh faktor alam, tetapi terkadang juga ulah manusia. Dalam sajak ini diingatkan agar manusia senantiasa menjaga kelestarian hutan karena merupakan habitat margasatwa dan mencegah bahaya banjir. Apabila hutan terbakar, satwa tidak memiliki tempat hidup lagi. Di samping itu, longsor dan banjir bandang bisa terjadi. Sajak tersebut secara tidak langsung merefleksikan nasionalisme dengan senantiasa menjaga lingkungan dan sumber daya alam Indonesia.

\section{Kesimpulan}

Dari uraian di atas dapat disimpulkan bahwa terdapat kandungan nilai-nilai nasionalisme dalam berbagai bentuk kritik sosial dalam teks puisi. Bentuk-bentuk kritik sosial yang mengekspresikan nasionalisme, antara lain berupa kritik terhadap masalah ekonomi, politik, pendidikan, moral, dan lingkungan. Dalam hal ini, nasionalisme dikemas dalam bentuk kritik sosial. Relasi antara bentuk-bentuk kritik sosial dan nasionalisme menunjukkan bahwa kritik sosial, baik dalam bidang ekonomi, politik, pendidikan, moral, maupun lingkungan, dipergunakan sebagai media atau sarana untuk menyampaikan nasionalisme. Hal tersebut disebabkan puisi menyatakan sesuatu secara tidak langsung. Puisi menyampaikan nilai-nilai nasionalisme melalui berbagai bentuk kritik sosial.

\section{Daftar Pustaka}

Abrams, M.H. 1981. A Glossary of Literary Terms. New York: Holt, Rinehart and Winston.

Damono, Sapardi Djoko. 1984. Sosiologi Sastra: Sebuah Pengantar Ringkas. Jakarta: Pusat Pembinaan dan Pengembangan Bahasa Departemen Pendidikan dan Kebudayaan.

Curtis, dkk. 1996. Komunikasi Profesional Bisnis. Jakarta: Rosda Jayapura.

Escarpit, Robert. 2005. Sosiologi Sastra. Yogyakarta: Yayasan Obor Indonesia.

Ismail, Taufik. 2000. Malu (aku) Jadi Orang Indonesia. Jakarta: Yayasan Indonesia.

Jassin, H.B. 1962. Kesusastraan Indonesia Modern dalam Kitik dan Esai. Jakarta: Gunung Agung.

Karmini, Ni Nyoman. 2017. "Fungsi dan Makna Sastra Bali Tradisional sebagai Pembentuk Karakter Diri:. Mudra: Jurnal Seni Bu- 
daya Vol. 32 No.2, Mei 2017, hlm. 149-161.

Kriyanto, Rachmat. 2006. Teknik Praktis Riset Komunikasi. Jakarta: Prenada.

Luxemburg, Jan van. 1984. Pengantar Ilmu Sastra. Jakarta: Gramedia.

Manuaba, Putra. 2014. "Eksotisme Sastra: Eksistensi dan Fungsi Sastra dalam Pembangunan Karakter dan Perubahan Sosial". Pidato Pengukuhan Jabatan Guru Besar dalam Bidang Sosiologi sastra pada fakultas Ilmu Budaya, Universitas Airlangga di Surabaya. Sabtu 6 September 2014. Surabaya: Airlangga University Press (AUP).

Ni'mah, Evayatun. 2017. "Pandangan Nasionalisme dalam Puisi Maḥmūd Darwisy dan Rendra dalam Analisis Sastra Banding". Pandangan Nasionalisme. Vol. 2, No, 1.

Panitia Dialog Borneo-Kalimantan XI bekerja sama dengan Dinas Pendidikan. 2011. Kalimantan dalam puisi Indonesia. Kalimantan Timur.

Pareira, Berthoid Auton. 2006. Kritik Sosial Politik Nabi Yesaya. Malang: Dioma.

Pradopo, Rachmat Djoko. 1997. PrinsipPrinsip Kritik Sastra. Cetakan Kedua. Yogyakarta: Gadjah Mada University Press.

2017. Pengkajian Puisi. Yogyakarta: UGM Press.

Purnawati, Ita. 2017. "Kritik Sosial dan Nasionalisme dalam Novel Gading-Gading Ganesha (3G) Karya Dermawan Wibisono. Skripsi. Program Studi Pendidikan Bahasa, Sastra Indonesia, dan Daerah, Universitas Mataram.

Putra, I Nyoman Darma. 2011. A Literary Mirror: Balinese Reflections on Modernity and Identity in the Twentieth Century. Leiden: KITVL.

Ratna, Nyoman Kutha. 2008. Teori, Metode, dan Teknik Penelitian Sastra. Yogyakarta: Pustaka Pelajar.

Rendra, W.S. 1984. Mempertimbangkan Tradisi. Jakarta: Gramedia. 1996. Potret Pembangunan dalam Puisi. Jakarta: Dunia Pustaka Jaya.

Riffaterre, Michael. 1978. Semiotics of Poetry. Bloomington-London: Indiana University Press.
Ritter, Herry. 1986. Dictionary of Concepts in History. New York: Greenwood Press.

Sari, Permata Angie. "Gagasan Nasionalisme Pramoedya Ananta Toer dalam Karya Tetralogi Buru". Skripsi. Jurusan Ilmu Pemerintahan Fakultas Ilmu Sosial dan Ilmu Politik, Universitas Diponegoro.

Smith, A. D. 1979. Nationalist Movement. London: The Macmillan Press.

Soemanto, Bakdi. 2001. Jagat Teater. Yogyakarta: Media Pressindo.

Susanto, Astrid. 1982. Komunikasi Massa. Bandung: Bina Cipta.

Snyder, L. L. 1964. The Dynamic of Nationalism. Princeton: D. Van Nostrand Co. Inc.

Taum, Yoseph Yapi. 2015. Sastra dan Politik: Representasi Tragedi 1965 dalam Negara Orde Baru. Yogyakarta: Universitas Sanata Dharma.

Thukul, Wiji. 1986. Peringatan. Tidak diterbitkan.

Teeuw, A. 2003. Sastra dan Ilmu Sastra. Jakarta: Pustaka Jaya.

Toda, Dami. 1980. Novel Baru Indonesia. Jakarta: Pustaka jaya.

Walzer, Michael. 1985. Interpretation and Social Criticism. Cambridge: Mass Harvard University Press.

Wildan. 2009. "Nasionalisme: Kajian Novel A. Hasjmy". Disertasi. Fakultas Sains Sosial dan Kemanusiaan, Universitas Kebangsaan Malaysia.

Wiyatmi. 2013. "Konstruksi Nasionalisme dalam Novel-Novel Indonesia Prakemerdekaan (Student Hijo dan Salah Asuhan)". Kawistara. Vol. 7, No. 6, hlm. 117-226.

\section{Daftar Laman}

Efendi, Anwar. 2008. Gagasan Nasionalisme dan Wawasan Kebangsaan dalam Novel Indonesia Modern. Dimuat dalam http:// staffnew.uny.ac.id/upload/ 132086367/ lainlainWawasan+Kebang-saan.doc. Diunduh pada 1 April 2019.

Thukul, Wiji. 1986. Peringatan. Dimuat dalam http://www.wijithukul.tk. Diunduh pada 2 April 2019.

1989. Gumam Sehari-hari. Dimuat dalam http://www.wijithukul.tk. Diun-duh pada 2 April 2019. 